\title{
AFL Umpires: Brand and Reputation
}

\author{
Rob Gill \\ Swinburne University of Technology \\ Communications Group, Melba Ave, Lilydale VIC 3140 \\ E-mail: rgill@swin.edu.au
}

Accepted: Sep 03, 2013 Published: October 10, 2013

Doi:10.5296/jsr.v4i2.4401

URL: http://dx.doi.org/10.5296/jsr.v4i2.4401

\begin{abstract}
The Australian Football League (AFL) acknowledges a potentially serious branding problem in relation to umpires. It is struggling to meet the operational demands of providing enough umpires to officiate in non-professional competitions administrated by the AFL.
\end{abstract}

It is believed AFL umpires have a poor reputation among the general public. This may provide a barrier to take up and present a significant source of motivational conflict for aspiring umpires. In particular this situation presents a challenge for marketing campaigns trying to recruit new umpires. The long term impact is significant, since without umpires at the grass roots level the future sustainability of AFL is brought into question.

This paper aims to determine the umpires' reputation and how this may impact on the AFL's ability to effectively market the need for and recruit umpires in non-professional leagues. This information can provide guidance for strategies used to improve umpire reputation, recruitment and retention.

Key words: Brand, Reputation, AFL Umpires, Public Perceptions, Track: Brands and Brand Management

\subsection{INTRODUCTION}

This paper analyses the Australian Football League (AFL) public's perception of AFL field umpires; in particular those umpires who officiate in the national professional league. It aims to establish the reputation AFL field umpires as a collective group have within the AFL public, and investigates determinants on why the particular reputation exists. There are concerns that deficient umpire recruitment and retention in non-professional AFL leagues may be influenced by a lowly reputation for AFL umpires and motivational conflict, particularly approach-avoidance conflict where potential umpires will avoid the risk and negativity related to being an umpire (Lantos, 2011). 
'Australian Rules' football is a game peculiar to Australia and was recognised as a unique sport with its own rules in 1858 (AFL, 2010). It is the most popular spectator sport in terms of attendance and television viewing in Australia and generates the highest annual revenue for any sport within Australia. The AFL commission is the governing body for 'Australian Rules' football.

The reason for the investigation into umpire reputation is: to ascertain if in fact there is a reputation problem, what may be identified as contributing negatively to the umpire's reputation and whether this is an issue for the AFL. The AFL has already identified as a marketing issue regarding the recruitment of umpires, and it is assumed that a poor reputation for umpiring may be a contributing factor to declining AFL umpire recruitment and retention across all levels of the game.

Reputation is defined as the estimation in which a person or thing is held by the community or the public generally (Macquarie, 1991). More specifically, reputation refers to the esteem in which the organisation (or individual) is held by its public and stakeholders (Beder, 2002; L'Etang, 2008). Brand is more than just a promise for the delivery of product/service, but is also an emotional connection to the consumer (Solomon, Hughes, Chitty, Fripp, Marshall \& Stuart, 2011). The perceptions that are shaped over time by stakeholders' experiences, along with the media, culminate in the public cumulative judgment of the organisation that defines the organisation's delivery on its promises - its reputation (Beder, 2002; Fombrun \& Shanley, 1990; L'Etang, 2008). Scott and Walsham (2005) refer to reputation issues being the gap between what an organisation promises (brand) and what it delivers (reputation). The risk to reputation is when the gap becomes significant, and can lead to an organisation's reputation being damaged (Gotsi \& Wilson, 2001).

This paper examines key brand facets to determine why AFL umpires have acquired a certain reputation, based on the football public's perceptions regarding: performance, consistency in interpretation, the number of rules, the use of technology, and the playing background of umpires. It reviews the AFL publics' perception of umpiring, the AFL's promotion of umpires and the media responses. Information is primarily sourced from the results of an online survey investigating the reputation of AFL umpires, along with a review of contemporary media regarding AFL umpiring.

\subsection{WHY UMPIRE REPUTATION IS IMPORTANT}

The AFL is effectively a corporation, as it is a united body working towards a business enterprise, even though it operates as a commission. Stakeholders in the AFL include corporate staff, players, team administration, spectators and game administration (AFL, 2012). The corporate brand is what the stakeholders are expecting the organisation to deliver. Umpires, as a representation of the AFL administration, contribute to the AFL's brand. The reputation of umpires can contribute considerably to the AFL's overall brand. 
The AFL brand, by virtue of being the largest supported sport within Australia, holds significant importance from a financial, social and ethical perspective. AFL games in 2012 had an attendance of 6.8 million (AFLTables, 2012). The viewing of television broadcasts for the games average between 2.9 and 5.3 million people per weekend during the season (thinktv, 2007). The AFL generates immense interest and wealth with annual revenue of more than $\$ 215$ million, a current television deal worth $\$ 1.25$ billion over five years and more than 300,000 media stories per year (convictcreations, 2012). Another expanding component to the impact of AFL is gambling, with millions of dollars wagered each week against game results (Munro, 2010). The AFL also significantly influences social and ethical issues for Australian society through its support for community and regional football development, and its very public policies on equality and racism (AFL, 2010; Munro, 2010).

Delivering on the AFL brand has considerable implications, in terms of social and financial support. AFL umpires play a strong part in the representation of the AFL brand to attendees and viewing spectators on game-days. There are a number of facets to the AFL umpire's brand, including: their ability to make consistent and fair decisions, the interpretation of the rules of the game, and the recent introduction of technology to decision making (McNicholl, 2013). The experiences that spectators, players, team administrators and the media have of umpires and how they perform these facets define the umpires' general reputation (as already stated above by Beder; Fombrun and Shanley; L'Etang). The risk to the AFL's reputation is that the public perceives umpires are not performing their role to a capable level. Also, participation numbers across Australia for AFL players at all levels is on the rise and it is forecast the gap between umpire supply and demand could exceed 20,000 by 2013 (Lane, 2010). It is critical to maintaining the AFL brand and improving umpire recruitment that umpires sustain a positive reputation.

\subsection{CURRENT INFLUENCES ON UMPIRE PERCEPTION}

\subsection{The AFL Commission}

The AFL appears to take the position that the general reputation of umpires is not as positive as it desires in order to protect the AFL brand. The AFL states on their website and through media releases that 20-25 per cent of umpires are giving up umpiring every year, due mainly to poor match day environments as a result of abuse and disrespect (AFL, 2010; Burgen, 2010). The AFL has implemented a number of promotional strategies and policies to influence the football public's opinion. They are working hard on improving the perception of umpires with initiatives such as: appreciation for umpires, fast-tracking ex-AFL players to elite umpiring status, and limiting negative comments to the media about umpiring by AFL personnel.

The AFL has recognised that positive marketing and promotion can have a major impact on the football public's perception for the umpires' reputation (Blyhe, 2006). 'Umpire Appreciation Round' and the 'Umpiring is Everyone's Business' campaign are acknowledgements by the AFL that all is not adequate with the reputation of umpires, and that a cultural change towards AFL umpires needs to occur (AFL, 2010, Wilson, 2010). The AFL 
has put in place a protection platform for umpire reputation by stipulating that under 'AFL Regulation 16.1:Public Comments on Umpires' any public comment by AFL players, coaches, officials and those teams regulated by the AFL against umpires are liable for fines of up to $\$ 20,000$ for a first offence (Sexton \& Russell, 2009). Effectively all AFL club officials are banned from making derogative comments regarding umpiring in order to set a positive example on conduct and attitudes towards umpires.

In a deliberate step by the AFL to raise the perceived connection between umpires and players, they are targeting and fast tracking ex-AFL players to the elite level of umpiring. The AFL umpiring department has joined forces with the AFL Players Association in an attempt to recruit former players to AFL league umpiring. The AFL has established the new 'Player to Umpire Pathway Academy', which helps to identify former players suitable to furthering their AFL careers through umpiring. AFL Umpiring Director, Jeff Gieschen, indicated that recently-retired players were extremely attractive to the AFL as potential umpires because they already had an understanding of elite sport, had achieved high levels of fitness and were used to the pressures associated with elite level sport (Bradshaw, 2010). However, only six ex-elite players have made the transition to top-tier umpiring since 1945.

\subsection{The Mass Media}

The media have also played a major role in the public reputation of AFL umpires. The traditional media make a significant contribution in defining what is topical, especially in sport (Harrison, 2008). Areas relating to umpiring that are highlighted and discussed by the media provide the information for which the AFL public base their own opinions on. The influence traditional media has on the public's opinion relating to topical issues is well documented (L'Etang, 2008). Should there be an identified problem with umpire reputation as it is represented through the media, then the AFL need to address their media relations' strategies for umpires.

A review of direct mentions for AFL umpires in the traditional media showed that 25 articles were printed in the daily Victorian newspapers of the 'Herald Sun' and 'The Age' over the 12-month review period of June 2009 - June 2010. Of those reviewed, 10 were judged to be negative or derogative about umpires or their decisions, 12 were judged to be positive or supportive about umpires and their decisions, and three made no judgment on the decisions or performances of umpires. Examples of positive topics included umpire appreciation round, umpire sponsorship, and targeting ex-players to be umpires. Negative media examples include clashing attire between umpires and players, poor decisions and poor positioning by umpires.

\subsection{AFL Public's Perceptions}

It is believed the AFL umpires' reputation as adjudicators of football games with its public is effectively diminished due to the gap between expectation and perception of delivery, as a result of one or a combination of the following facets: 


\section{$\Lambda$ Macrothink}

- The rules are open to different interpretations between field umpires

- Too many rules in the game for umpires to remember

- Three umpires on the field in charge of the game is too many

- Lack of technology to aid decisions

- Too many AFL umpires who don't come from a high-level playing background

To investigate this, research was conducted through an anonymous online survey specifically designed to gather information from the AFL public regarding their perceptions of umpiring and the rules (see: ......, 2012). The online survey was made available through a web-link and was distributed amongst the AFL public via email requests, posting on club websites and supporters' social media sites. The 14-question survey was designed to provide quantitative data relating to public perceptions on the above facets. More than 300 respondents completed the survey.

Table One - Summary of results: Umpires Reputation Survey

\begin{tabular}{|c|c|}
\hline Question & Quantitative Results \\
\hline 1 & Respondents' gender: 289 male, 29 female respondents, 1 no answer \\
\hline 2 & $\begin{array}{l}\text { Respondents' ages in years: } 170 \text { over } 35,120 \text { between } 20-35,20 \text { between } 15-19 \text {, } \\
\text { and } 7 \text { under } 15 \text { years, } 2 \text { no answer }\end{array}$ \\
\hline 3 & $\begin{array}{l}\text { Football background for respondents: } 2 \text { AFL, } 62 \text { semi-professional, } 107 \\
\text { social/amateur, } 90 \text { as under-age players only, } 57 \text { never played, } 1 \text { no answer }\end{array}$ \\
\hline 4 & Performance at AFL level: $125 / 5,108$ at 4/5, $1013 / 5,612 / 5,1 / 5,3$ no answer \\
\hline 5 & $\begin{array}{l}\text { Opinion on what most think of AFL umpires: } 6 \text { great, } 87 \text { good, } 148 \text { average, } 73 \\
\text { poor, } 5 \text { no answer }\end{array}$ \\
\hline 6 & $\begin{array}{l}\text { Umpire performance in other leagues: } 15 \text { excellent, } 78 \text { very good, } 126 \text { good, } 38 \\
\text { average, } 14 \text { poor, } 44 \text { not applicable, } 4 \text { no answer }\end{array}$ \\
\hline 7 & $\begin{array}{l}\text { Difficulty in predicting an umpires decision: } 15 \text { never, } 233 \text { sometimes, } 57 \text { most } \\
\text { of the time, } 12 \text { all of the time, } 2 \text { no answer }\end{array}$ \\
\hline 8 & $\begin{array}{l}\text { Too many rules in Australian Rules Football: } 150 \text { yes, } 143 \text { no, } 23 \text { unsure, } 3 \text { no } \\
\text { answer }\end{array}$ \\
\hline 9 & Each umpire interprets the rules the same: 55 yes, 242 no, 20 unsure, 2 no answer \\
\hline 10 & $\begin{array}{l}\text { Times AFL umpires make clear mistakes: } 67 \text { less than } 3 \text {, between } 4-6123 \text {, } \\
\text { between } 6-966,10 \text { or more } 60,3 \text { no answer }\end{array}$ \\
\hline 11 & $\begin{array}{l}\text { More or less AFL umpires in charge: } 31 \text { more, } 65 \text { less, } 1913 \text { field umpires is the } \\
\text { right } \\
\text { number, } 25 \text { unsure, } 7 \text { not answered }\end{array}$ \\
\hline 12 & Video review for difficult decisions: 98 yes, 216 no, 5 not answered \\
\hline 13 & $\begin{array}{l}\text { Umpires needed from high-level playing backgrounds: } 111 \text { yes, } 17 \text { no, } 188 \text { not a } \\
\text { necessity, } 3 \text { no answer }\end{array}$ \\
\hline 14 & Further comments: 156 (see breakdown below) \\
\hline
\end{tabular}

The survey results indicate that the majority of respondents (70 per cent) rated AFL field umpires as doing a good to excellent job at adjudicating football games. Thus, the AFL umpires' reputation with its public as adjudicators of the games is effectively positive. In fact, 
almost 81 per cent believed umpires in non-professional leagues do a good to excellent job. Even considering many of the media reports from the daily Victorian newspapers relating directly to umpiring focus on negative aspects, this does not seem to have had a significant and adverse effect on the AFL public's perception on the performance of umpires. Therefore, it can be said that the field umpires' reputation is held in 'healthy' regard with the AFL public. This reflects an AFL Commission's investigation into perceptions on the standards of umpiring with AFL league clubs, that had previously identified no critical issues with the umpires' reputation (Sanders, 2003).

However, what is evident from the survey results is that 70 per cent of the AFL public believes the field umpires often have different interpretations of the same rule that produces inconsistencies in decision-making. An overwhelmingly 95 per cent indicated they sometimes, often or always found it difficult to predict what the umpires' interpretations would be. This suggests the AFL need to address internal understanding for, and consistent application of, the rules across all leagues - as decisions made on these rules ultimately reflect negatively on the umpires' reputation.

An important observation from the survey is that many respondents (around 50 per cent) contributed to the optional comments section, demonstrating that many of the survey participants had a strong desire to express their opinion on the performance of the umpires and rules for the game. Therefore, umpiring does play a considerable role in the AFL experience for many supporters, players and administrators, and ultimately has an influence on the AFL's reputation. This has significant implications for the ongoing management of relationships between the AFL and its public regarding the role and performance of umpires.

\section{SUMMARY AND CONCLUSION}

In conclusion, the AFL umpires' performance has been shown to be of an acceptable standard by its football public. Based on the results of the survey, there appears to be no immediate risk to the AFL's brand as a result of the umpires' perceived ability to effectively adjudicate games of football. The current reputation of umpires from the AFL public's perceptions is generally sound. What needs to be considered are the rules and interpretations of the rules, according to survey responses and media analysis.

Based on the findings of this paper the AFL commission will need to investigate other influences on the current marketing and promotion campaigns used to address the umpire shortage for non-professional leagues at all levels around Australia. Proactive media relations from the AFL commission regarding umpiring appear not to be having the desired effect as these umpire shortages continue to be an issue, as recent indication have flagged an umpire shortage of more than 8,000 (Sullivan, 2013).

As the recruitment and retention of umpires does not appear to be linked to the AFL public's perceptions of umpires, there needs to be further investigations into the marketing and 
promotion process for umpiring by the AFL, and other adverse influences on the motivation of people to become AFL umpires.

\section{REFERENCES}

AFL (2013). Laws of Australian Football 2013. Melbourne: Australian Football League

AFL (2010). AFL History. Australian Football League, Retrieved June 16, 2010 from http://www.afl.com.au/history/tabid/10296/default.aspx

AFL (2012). 2012 AFL Statistics. Australian Football League Retrieved June 16, 2010 from http://www.afl.com.au/Premiership/Statistics/tabid/73/Default.aspx

AFLTables (2012) Game Attendances 2012 Retrieved June 16, 2013 from http://www.aflstats.tk

Barringer, T. A. (2001). Book Reviews. The Round Table, 90 (361), 639-659.

Beder, S. (2002). Environmentalists help manage corporate reputation: changing perceptions not behaviour. Ecopolitics, 1 (4), 60-72.

Blythe, J. (2006). Principles and Practices of Marketing. London: Thomson.

Bradshaw, F. (2010, June 22). Former Blue and Bomber Jordan Bannister is aiming to rejoin AFL ranks as an umpire. Herald Sun Online. Retrieved June 22, 2010 from http://www.heraldsun.com.au/sport/afl/former-blue-jordan-bannister-training-to-be-an-um pire/story-e6frf9jf-1225799627528

Burgen, M. (2010, May 13). Respect for Umpires Still A Work in Progress. AFL News. Retrieved June 21, $2010 \quad$ from http://www.afl.com.au/tabid/208/default.aspx?newsid=94235

Convictcreations. (2012). Battle of the Codes Statistics. Retrieved June 16, 2013 from http://www.convictcreations.com/football/battlestats.html

Fombrun, C. \& Shanley, M. (1990). What's in a name? Reputation building and corporate strategy. Academy of Management Journal, 33, 233-258.

Gardner, S., James, M., O’Leary, J. \& Welch, R. (2006). Sports Law. London: Cavendish Publishing.

Gotsi, M. \& Wilson, A. (2001). Corporate Reputation: seeking a definition. Corporate Communication: An International Journal, 16 (1), 24-30.

Gill, R. (2012) Does Brand Matter for AFL Umpires? International Journal for Academic Research in Business and Social Sciences, Volume 2, no. 4, pp 639-648. http://hrmars.com/index.php?page $=$ v2i5\%20(ijarbss)\&CAT $=1$

Harrison, K. (2008). Strategic Public Relations ( $4^{\text {th }}$ Ed.). Perth: Century Consulting.

Harrison, J. \& Hirst, M. (2006). Communication and New Media: From Broadcast to Narrowcast. Melbourne, Oxford University Press.

Lane, S. (2010, June 16). Umpire Spit, Abuse Allegations. The Age. Melbourne: Fairfax News Ltd.

Lantos, G.P. (2011). Consumer Behavior in Action: Real-Life Applications for Marketing Managers, New York: ME Sharpe Inc.

L'Etang, J. (2008). Public Relations. Concepts, Practice and Critique. London: Sage. 


\section{Mll Macrothink}

Journal of Sociological Research

ISSN 1948-5468 2013, Vol. 4, No.2

MacFarlane, G. (2010, February 14). Changing Places. Herald Sun. Melbourne: News Limited.

Macquarie Dictionary. (1991). The Macquarie Dictionary (2nd Ed.). NSW: The Book Printer.

McNicholl, A. (2013, April 29). Video review system not perfect, but set to stay: AFL. AFL News:

http://www.afl.com.au/news/2013-04-29/video-review-system-not-perfect-but-set-to-stay-a $f l$

Munro, P. (2010, September 19). How footy fuels state economy, The Age, Melbourne: Fairfax News Ltd.

Sanders, W.B. (2103) National Review of Umpiring, AFL: http://mm.afl.com.au/Portals/0/afl_docs/Development/national_review_of_umpiring.pdf

Scott, S. \& Walsham, G. (2005). Reconceptualizing and Managing Reputation Risk in the Knowledge Economy: Toward Reputable Action. Organization Science, May/June 2005, 16 (3), 308-322.

Searle, J. (1995).The Construction of Social Reality. New York: Free Press.

Sexton, R. \& Russell, M. (2009, May 3). Is it time to shift the goalposts on umpires?. Sydney Morning Herald. Sydney: Fairfax Media, Retrieved June 17, 2010 from http://www.smh.com.au/afl/afl-news/is-it-time-to-shift-the-goalposts-on-umpires-2009112 4- j5oo.html .

Solomon, Hughes, Chitty, Fripp, Marshall, Stuart (2011). Marketing 2: real people real choices. Pearson: NSW.

Stewart, B., Smith A. \& Nicholson, M. (2003). Sports Consumer Typologies: A critical review. Sports Marketing Quarterly, 12 (4), 206-216.

Sullivan, J. (2013, May 1). Umpire bashing reignites safety debate. ABC News Online: http://www.abc.net.au/news/2013-05-01/umpire-bashing-reignites-safety-debate/4663764

Thinktv. (2007, June 14). Statistics. Thinktv, Retrieved June 16, 2010 from http://www.thinktv.com.au/media/Medi...Jan-Jun_07.pdf .

Wilson, C. (2010, February 12). "Shake on it: AFL plan to boost umpire respect". The Age $\begin{array}{lllll}\text { Online. } & \text { Retrieved } & \text { June } & 22, & \text { from }\end{array}$ http://www.theage.com.au/afl/afl-news/shake-on-it-afl-plan-to-boost-umpire-respect-2010 0211-nv39.html . 